\title{
RESEARCH ON CREDIT RISK IDENTIFICATION OF REAL ESTATE INDUSTRY IN CHINA 'S COMMERCIAL BANKS
}

\author{
Yifan Huang \\ Shanghai University, P.R. China
}

\begin{abstract}
The core competitiveness of commercial banks is reflected in the ability of risk management, and the most important of all risk management is credit risk management. In addition, for commercial banks, real estate loans are a very important source of income, therefore, investment in real estate funds has increased, but the real estate business non-performing loan rate continues to rise. At present, the real estate industry has been included in the high-risk industries, therefore, to strengthen the real estate credit risk identification for the healthy development of the bank is very important. In the paper, credit risk is briefly introduced, including concept, classification and identification methods. Then we introduce the Z-score model, which is measured the credit risk. We find that the result is not very accurate, so we revised the model considering the situation of our country and the characteristics of the real estate industry. Finally, the $\mathrm{Z}$ model is prospected on the basis of the theoretical exposition.
\end{abstract}

Key Words: Credit risk, Z score model, Fisher test, Real estate industry

JEL code: M0, M1

\section{Introduction}

\subsection{Research Background and Significance}

The financial turmoil triggered by the US subprime mortgage crisis in 2007 swept the world, many commercial banks in developed countries suffered heavy losses. The company's asset quality continued to decline, loan losses continued to rise, and credit risk improved significantly. The world economy suffered a huge blow. The financial crisis exposed that there is a huge loophole in the financial system and financial regulatory system. In order to repair this loophole, the Financial Stability Board and the Basel Committee had carried out a series of fundamental reforms about the regulation of international finance to enhance the stability of banking loans. December 2010, the Basel Committee issued the third edition of the Basel Accord. At the same time, credit risk was one of the major risks faced by commercial banks, and strengthening credit risk management would help to enhance the stability of banking loans. 
China's real estate industry leads the development of all walks of life. Mortgage market is expanding, and the real estate credit risk is becoming more and more obviously. With the real estate market uncertainty increased, the real estate loan risk chain effect is likely to reproduce to affect China's economic development.

Credit risk has always been one of the major risks faced by China's commercial banks. The paper is based on the Basel III, combining with the status of credit risk identification and management in China. According to China's real estate industry's specific national condition, the paper amends the $\mathrm{Z}$ model in order to identify the credit risk of China's real estate industry.

\subsection{Literature Review}

The measurement and management of credit risk is the core problem of commercial banks. The accurate measurement and effective management of credit risk is conducive to the safety of commercial banks and the stability of the financial system. At present, mathematical analysis has become the main method of credit risk identification model, which can avoid the defects caused by human factor. Mathematical analysis provides a good basis for the credit risk management of financial institutions.

\subsubsection{Literature Review Abroad}

Maria (2016) proposed a new dynamic modeling framework for credit risk assessment that extended the prevailing credit scoring models built upon historical data static settings. The driving idea mimicked the principle of films, by composing the model with a sequence of snapshots, rather than a single photograph.

Guilherme and Rinaldo (2016) proposed a measure of the local risk of default based on the application of ordinary kriging, from a data set with the localization and default information of 9 million Brazilian SMEs. This variable had been included in logistic credit scoring models as an explanatory variable. These models had shown better performance when compared to models without this variable.

Guo, Zhou, Luo and Liu (2016) designed an instance-based credit risk assessment model, which had the ability of evaluating the return and risk of each individual loan. Moreover, they formulated the investment decision in P2P lending as a portfolio optimization problem with boundary constraints. To validate the proposed model, they performed extensive experiments on real-world datasets from two notable P2P lending marketplaces. Experimental results revealed that the proposed model can effectively improve investment performances compared with existing methods in P2P lending.

Geonwoo and Eunho (2016) studied the valuation of Exchange option with credit risk. For modeling of credit risk, they used the structural model of Klein. They derived the closed-form pricing formula for the price of the Exchange option with credit risk via the Mellin transform 
and provided the experiment results to illustrate the important properties of option with numerical graphs.

Johanna, Nadine and Michael (2016) emphasized that the consideration of credit risk associated with bonds had a strong impact on the fair valuation and risk measurement in the context of participating life insurance contracts, even in case of higher grade bond exposures.

In 1968, Altman presented the famous Z-score model. Z score model is a multiple regression analysis model, by choosing the metrics that can reflect the borrower's financial position. Altman designed the mathematical $\mathrm{Z}$ model that can identify the probability of credit risk.

In 1977, Altman and extended and revised the Z-score model. They proposed the second-generation credit score model-ZETA credit risk model. The variables of the new model increased from five to seven in the $\mathrm{Z}$ model.

\subsubsection{Domestic Literature Review}

Luo and Chen (2017) built two categories of Logistic credit risk assessment model, and used the sample data of a bank named China Everbright Bank to assess the credit risk of personal financial micro credit. The results showed that the factors such as customer's gender, educational background, age, income, occupation, occupation and so on had a significant influence on individual micro credit risk.

Gao, Du and Tong (2017) took the 103 listed companies in Shanghai and Shenzhen stock markets from 2009 to 2013 as the research samples, and used the KMV model to demonstrate the credit risk.

Deng (2016) investigated the situation about credit risk of commercial banks and the current situation of credit risk management in China, and putted forward some suggestions for risk management mechanisms.

Yang and Jiang (2016) analyzed the four kinds of credit risk management methods, which were KMV model, Credit Metrics model, Credit Risk + model and Credit Portfolio View model. The four methods were based on qualitative and quantitative analysis.

Gao (2016) researched on the application of Moodie rating method and KMV method in China's real estate credit risk assessment, and proved the applicability and validity of Moody's rating method in the credit risk evaluation.

Through the above literature, we can clearly find a feature: most of domestic scholars and foreign scholars focused on the listed companies, but rarely on one specific industry research. Therefore, the paper will aim at the real estate industry company to launch the research, and mainly use the $\mathrm{Z}$ scoring model. 
Credit risk has always been one of the major risks faced by China's commercial banks. The paper is based on the Basel III, combining with the status of credit risk identification and management in China. According to China's real estate industry's specific national condition, the paper amends the $\mathrm{Z}$ model in order to identify the credit risk of China's real estate industry.

\section{The Commercial Bank Credit Risk}

Commercial bank is an important part of China's financial industry, its main function is to operate the deposit and loan business. Nowadays, the financial environment of our country is becoming more and more diversified, the financial products are innovating constantly, and the banking business field is widening and the risks are becoming more and more complicated.

According to different standards, the risk of commercial banks can be divided into different types, the most common classification standard is based on the Basel agreement "effective core principles of banking supervision" to classify the risk. The risk of commercial banks is divided into eight categories: credit risk, operational risk, market risk, interest rate risk, liquidity risk, state and transfer risk, legal risk and reputation risk.

\section{Credit Risk Identification Method}

\subsection{Expert Analysis}

Expert analysis is one method that experts assess the enterprise credit risk by using their own economics expertise knowledge and their own subjective judgments. One of the most widely used methods is the five $\mathrm{C}$ method, that is, analyzing and judging the credit of a loan enterprise from character, capital, solvency, collateral and the environment five aspects.

\subsection{Loan Rating Method}

The loan rating method determines the size of the credit risk based on the different levels of the loan. China's loan quality is divided into normal loans, concerned loans, subprime loans, suspicious loans and loss loans.

\subsection{Credit Risk Measurement Model}

The credit risk measurement model is based on the regression analysis of the company's financial data to predict the possibility of bankruptcy, so as to identify the company's credit risk. There are four important models: KMV model, Morgan's Credit Portfolio View model, Credit Risk + model and Credit Porifolio View model. 


\section{Credit Risk Identification of Real Estate Industry Based on Z Model}

\subsection{Model Design}

In 1968, Altman presented the famous Z-score model. Z score model is a multiple regression analysis model. $Z$ score model is based on mathematical statistics to take statistical analysis on the bank loan case. By choosing the metrics that can reflect the borrower's financial position, Altman designed a mathematical model that can determine the probability of credit risk. The Z-score model can identify the credit risk of the loan applicant. Altman has studied five indicators as independent variable of the model. The discriminant formula of the $\mathrm{Z}$ model and the meaning of each variable are shown below:

$\mathrm{Z}=1.2 \mathrm{X} 1+1.4 \mathrm{X} 2+3.3 \mathrm{X} 3+0.6 \mathrm{X} 4+0.999 \mathrm{X} 5$

Among them, $\mathrm{X} 1=$ operating capital/total assets, $\mathrm{X} 2=$ retained earnings/total assets, $\mathrm{X} 3=$ $\mathrm{EBIT} /$ total assets, $\mathrm{X} 4=$ equity market price/liability face value, $\mathrm{X} 5=$ sales revenue/total assets.

Altman defined the regional $\mathrm{Z}$ model by means of the empirical analysis, as shown below:

Table 1: Critical range of the $\mathrm{Z}$ model

\begin{tabular}{|c|c|}
\hline Section & Discriminant result \\
\hline $\mathrm{Z}<1.81$ & The financial situation is worrying \\
\hline $1.81 \leqslant \mathrm{Z} \leqslant 2.675$ & More likely to get into financial trouble \\
\hline $2.675<\mathrm{Z}<2.99$ & There may be a financial distress \\
\hline $\mathrm{Z} \geqslant 2.99$ & No financial distress \\
\hline
\end{tabular}

\subsection{Sample and Data Selection}

The $\mathrm{Z}$ model has four definitions of financial distress: the first is that the company is terminated by bankruptcy and cannot repay the debt; secondly, the company is taken over by bankruptcy; thirdly, the situation is a legal dispute arising from a breach of contract or a breach of the law; Finally, the situation is liquidity problem or insolvency.

In 1998, our country implemented the ST policy, that was the special treatment policy, which mainly aimed at some companies which had the unusual operation. Therefore, the paper chooses ST companies as companies which have financial trouble, while selecting the same amount, the similar size companies which have no financial distress to identify the credit risk.

Here, the following $10 \mathrm{ST}$ companies and 10 non-ST companies are selected to compare and identify credit risks. 
Table $2 . \mathrm{Z}$ model index data

\begin{tabular}{|c|c|c|c|c|c|c|}
\hline & $\mathrm{X} 1$ & $\mathrm{X} 2$ & $\mathrm{X} 3$ & $\mathrm{X} 4$ & $\mathrm{X} 5$ & Z \\
\hline $\begin{array}{l}* \mathrm{ST} \\
\mathrm{XiTan}\end{array}$ & 4.7114 & 4.4354 & 2.3686 & 565.391 & 29.3164 & 3.8820 \\
\hline $\begin{array}{l}* \mathrm{ST} \\
\text { YingFang }\end{array}$ & -47.7651 & -33.8128 & -21.9804 & 58.6588 & 63.0908 & $-\mathbf{0 . 7 8 9 7}$ \\
\hline $\begin{array}{l}\text { STCheng } \\
\text { Cheng }\end{array}$ & -3.6166 & -26.4476 & 7.9760 & 792.375 & 99.7905 & 5.6007 \\
\hline $\begin{array}{l}\text { ST } \\
\text { HuiQiu }\end{array}$ & -39.9816 & -21.4052 & -19.4404 & 190.472 & 2.9277 & -0.248 \\
\hline $\begin{array}{l}\text { *ST } \\
\text { ZhuJiang }\end{array}$ & -13.2922 & -65.8296 & -6.1950 & 262.195 & 10.4389 & 0.3919 \\
\hline $\begin{array}{l}* \mathrm{ST} \\
\text { HengLi }\end{array}$ & -23.4142 & -44.1018 & -27.2381 & 86.8419 & 30.4314 & -0.9722 \\
\hline $\begin{array}{l}* \mathrm{ST} \\
\text { XinMei }\end{array}$ & -12.7168 & 2.1591 & -1.6268 & 673.124 & 17.0955 & 4.0335 \\
\hline STYaTai & -10.7897 & -5.1416 & -5.6016 & 152.310 & 7.5599 & 0.6031 \\
\hline $\begin{array}{l}\text { *STHong } \\
\text { Sheng }\end{array}$ & $-1,863.273$ & $-2,049.719$ & $-2,019.4473$ & 9.6904 & 18.7500 & -117.45 \\
\hline $\begin{array}{l}* \mathrm{ST} \\
\text { XingYe }\end{array}$ & -125.1013 & $-2,461.074$ & -60.1347 & 549.999 & 14.5831 & -34.495 \\
\hline $\begin{array}{l}\text { TianBao } \\
\text { JiJian }\end{array}$ & 64.4436 & 22.7451 & 3.2025 & 314.373 & 19.7454 & 3.2809 \\
\hline $\begin{array}{l}\text { YueHong } \\
\text { Yuan A }\end{array}$ & 31.2951 & 12.1180 & 2.1175 & 136.500 & 26.1113 & 1.6949 \\
\hline $\begin{array}{l}\text { ZhuJiangS } \\
\text { hiYe }\end{array}$ & 57.8015 & 21.4437 & 11.2355 & 102.923 & 44.4046 & 2.4257 \\
\hline $\begin{array}{l}\text { GuangYu } \\
\text { FaZhan }\end{array}$ & 12.1358 & -4.2312 & 3.9011 & 306.699 & 33.2666 & 2.3877 \\
\hline $\begin{array}{l}\text { KongGang } \\
\text { GuFen }\end{array}$ & 13.5400 & 14.4037 & 7.5302 & 104.023 & 47.0546 & 1.7068 \\
\hline $\begin{array}{l}\text { GaoXin } \\
\text { FaZhan }\end{array}$ & 1.0078 & -1.4243 & 4.3272 & 53.7549 & 27.5772 & 0.7330 \\
\hline $\begin{array}{l}\text { ShaHe } \\
\text { GuFen }\end{array}$ & 56.6242 & 20.3095 & 4.2085 & 183.928 & 22.8823 & 2.4349 \\
\hline $\begin{array}{l}\text { YuanChen } \\
\text { HuangJin }\end{array}$ & -22.1519 & -22.3950 & 0.9024 & 97.7659 & 24.9665 & 0.2864 \\
\hline $\begin{array}{l}\text { RongFeng } \\
\text { KongGu }\end{array}$ & 39.3586 & 27.6795 & 23.2454 & 507.473 & 259.030 & 7.2595 \\
\hline $\begin{array}{l}\text { JinYu } \\
\text { CheCheng }\end{array}$ & 4.9645 & -4.7556 & 2.9093 & 493.164 & 32.4327 & 3.3720 \\
\hline
\end{tabular}




\subsection{Z model Empirical Evaluation}

As you can see from the above table, the black bold section is the $\mathrm{Z}$ model identifying result that the company has financial difficulties. The top 10 listed companies are the companies which have financial difficulties, the second 10 companies are non-ST companies. It is obvious that comparing the $\mathrm{Z}$ model result and the real situation of listed company in our country, we can draw a conclusion that the original model cannot distinguish the financial status of the real estate listed companies very accurately.

Many scholars in China have studied the risk identification of companies with the $\mathrm{Z}$ model, but we also should consider the following two problems: the first one is that the model variables cannot be directly copied to our country to reflect the real situation in China; The second one is that $\mathrm{Z}$ score model does not design index variables by industry, and there are no suitable index variables for the real estate industry.

To sum up the two problems, the paper will revise the index variables of $Z$ model, according to the financial environment of our country, so as to improve the accuracy of $Z$ model for the risk identification of China's real estate industry.

\subsection{Revision of $Z$ Model}

\subsubsection{Reasons and Methods for $Z$ Model Correction}

In 2007 the U.S. subprime mortgage crisis exposed the problem of "Basel Capital Accord II", In 2010, Basel Bank regulators putted forward amendments to develop a new regulatory standard in the development direction of the various countries. In September 2010, 27 national central banks adopted a new banking regulatory agreement in Switzerland, the Basel capital accord iii. "Basel Capital Accord III" included the reform of bank capital and liquidity regulation, putting forward the requirement of improving capital quality and quantity, using leverage as a safety net, establishing capital flow into the buffer, the global minimum liquidity standards and other aspects.

The paper refers to the latest introduction of the "Basel Capital Agreement $\square$ ", and according to China's national conditions and the characteristics of China's real estate, three index variables $\mathrm{X} 6, \mathrm{X} 7$ and $\mathrm{X} 8$ will be introduced to China's real estate industry credit risk identification. X6 represents net cash flow/total assets. X7 represents receivable/total assets. $\mathrm{X} 8$ represents inventory/total assets.

\subsubsection{Model Setting}

Here the following 10 ST companies and 10 non-ST companies are selected to compare and identify credit risks.

The function of the model is in the form of: 
$\mathrm{Z}=\mathrm{C}+\mathrm{a} 1 \mathrm{X} 1+\mathrm{a} 2 \mathrm{X} 2+\mathrm{a} 3 \mathrm{X} 3+\mathrm{a} 4 \mathrm{X} 4+\mathrm{a} 5 \mathrm{X} 5+\mathrm{a} 6 \mathrm{X} 6+\mathrm{a} 7 \mathrm{X} 7+\mathrm{a} 8 \mathrm{X} 8$

Among them, $\mathrm{X} 1=$ operating capital/total assets, $\mathrm{X} 2=$ retained earnings/total assets, $\mathrm{X} 3=$ $\mathrm{EBIT} /$ total assets, $\mathrm{X} 4=$ equity market price/liability face value, $\mathrm{X} 5=$ sales revenue/total assets, $\mathrm{X} 6=$ net cash flow/total assets, $\mathrm{X} 7=$ accounts receivable/total assets, $\mathrm{X} 8=$ inventory/total assets, $\mathrm{C}$ is a constant.

Table $3 . \mathrm{Z}$ model index data

\begin{tabular}{|c|c|c|c|c|c|c|c|c|}
\hline & $\mathrm{X} 1$ & $\mathrm{X} 2$ & $\mathrm{X} 3$ & $\mathrm{X} 4$ & $\mathrm{X} 5$ & X6 & $\mathrm{X} 7$ & $\mathrm{X} 8$ \\
\hline $\begin{array}{l}{ }^{* S T} \\
\text { XiTan }\end{array}$ & 4.7114 & 4.4354 & 2.3686 & 565.3912 & 29.3164 & -11.93 & 15.3100 & 0.7800 \\
\hline $\begin{array}{l}{ }^{*} \text { ST } \\
\text { YingFang }\end{array}$ & -47.76 & -33.81 & -21.9804 & 58.6588 & 63.0908 & 0.51 & 27.2300 & 31.6900 \\
\hline $\begin{array}{l}\text { STCheng } \\
\text { Cheng }\end{array}$ & -3.616 & -26.44 & 7.9760 & 792.3751 & 99.7905 & 7.02 & 68.2000 & 0.4300 \\
\hline $\begin{array}{l}\text { ST } \\
\text { Hui Qiu }\end{array}$ & -39.98 & -21.4 & -19.4404 & 190.4725 & 2.9277 & 3.77 & 0.2800 & 0.6800 \\
\hline $\begin{array}{l}* \text { ST } \\
\text { Zhu Jiang }\end{array}$ & -13.29 & -65.83 & -6.1950 & 262.1953 & 10.4389 & -6.77 & 30.3700 & 0.2400 \\
\hline $\begin{array}{l}\text { *ST } \\
\text { Heng Li }\end{array}$ & -23.41 & -44.1 & -27.2381 & 86.8419 & 30.4314 & -18.97 & 1.7100 & 1.9000 \\
\hline $\begin{array}{l}\text { *ST } \\
\text { Xin Mei }\end{array}$ & -12.71 & 2.1591 & -1.6268 & 673.1249 & 17.0955 & -4.71 & 501.550 & 0.3400 \\
\hline STYaTai & -10.78 & -5.14 & -5.6016 & 152.3107 & 7.5599 & 2.78 & 3.5200 & 1.2300 \\
\hline $\begin{array}{l}\text { *STHong } \\
\text { Sheng }\end{array}$ & $-1,863$ & $-2,049$ & $-2,019.4$ & 9.6904 & 18.7500 & -3.44 & 0.0100 & 4.9500 \\
\hline $\begin{array}{l}\text { *ST } \\
\text { XingYe }\end{array}$ & -125.1 & $-2,461$ & -60.1347 & 549.9995 & 14.5831 & -27.03 & 1.7500 & 1.9300 \\
\hline $\begin{array}{l}\text { TianBao } \\
\text { JiJian }\end{array}$ & 64.44 & 22.745 & 3.2025 & 314.3737 & 19.7454 & 9.28 & 433.810 & 0.3300 \\
\hline YueHong & 31.29 & 12.118 & 2.1175 & 136.5002 & 26.1113 & -11.13 & 16.4500 & 0.5000 \\
\hline
\end{tabular}


Table 3, cont.

\begin{tabular}{|l|l|l|l|l|l|l|l|l|}
\hline Yuan A & & & & & & & & \\
\hline ZhuJiang & 57.80 & 21.443 & 11.2355 & 102.9235 & 44.4046 & 7.08 & 72,464 & 0.5200 \\
\hline $\begin{array}{l}\text { ShiYe } \\
\text { FaZhangYu }\end{array}$ & 12.13 & -4.231 & 3.9011 & 306.6992 & 33.2666 & 17.76 & 7.5200 & 0.4700 \\
\hline $\begin{array}{l}\text { KongGang } \\
\text { GuFen }\end{array}$ & 13.54 & 14.403 & 7.5302 & 104.0230 & 47.0546 & 9.59 & 4.4500 & 0.6900 \\
\hline $\begin{array}{l}\text { GaoXin } \\
\text { FaZhan }\end{array}$ & 1.007 & -1.424 & 4.3272 & 53.7549 & 27.5772 & 8.59 & 4.2000 & 0.4500 \\
\hline $\begin{array}{l}\text { ShaHe } \\
\text { GuFen }\end{array}$ & 56.62 & 20.309 & 4.2085 & 183.9285 & 22.8823 & -14.39 & 103.250 & 0.2500 \\
\hline $\begin{array}{l}\text { YuanChen } \\
\text { HuangJin }\end{array}$ & -22.15 & -22.39 & 0.9024 & 97.7659 & 24.9665 & -10.32 & 2.5000 & 1.8700 \\
\hline $\begin{array}{l}\text { RongFeng } \\
\text { KongGu }\end{array}$ & 39.35 & 27.679 & 23.2454 & 507.4731 & 259.030 & -30.65 & 37.8800 & 5.6100 \\
\hline $\begin{array}{l}\text { JinYu } \\
\text { CheCheng }\end{array}$ & 4.964 & -4.755 & 2.9093 & 493.1643 & 32.4327 & -5.07 & 23.8900 & 2.0400 \\
\hline
\end{tabular}

\subsubsection{Establish Fisher Discriminant}

The paper uses the Fisher linear discriminant method, and the 8 index variables are independent variables, and the $\mathrm{Z}$ value is the dependent variable. The discriminant model is established to identify the credit risk.

The function form of the Fisher discriminant equation is:

$\mathrm{Z}=\mathrm{C}+\mathrm{a} 1 \mathrm{X} 1+\mathrm{a} 2 \mathrm{X} 2+\mathrm{a} 3 \mathrm{X} 3+\mathrm{a} 4 \mathrm{X} 4+\mathrm{a} 5 \mathrm{X} 5+\mathrm{a} 6 \mathrm{X} 6+\mathrm{a} 7 \mathrm{X} 7+\mathrm{a} 8 \mathrm{X} 8$

The Fisher discriminant method discriminant process includes deriving a discriminant equation which is based on the classification of the known sample and the financial variable. And then the independent variables of each sample are returned to the function. Determine the category of the sample according to the discriminant equation. Then the prediction accuracy is calculated by the sample. These processes are accomplished by SPSS. The paper uses 0 to represent non-ST companies, and 1 to represent ST companies. The discriminant equation is derived by SPSS, and the results are as follows. 
Table 4. Fisher analysis discrimination results

\begin{tabular}{|l|c|}
\hline \multicolumn{1}{|c|}{$\mathrm{C}$} & -0.704 \\
\hline $\mathrm{X} 1=$ operating capital / total assets & -0.038 \\
\hline $\mathrm{X} 2=$ retained earnings / total assets & 0.001 \\
\hline $\mathrm{X} 3=$ EBIT/ total assets & 0.033 \\
\hline $\mathrm{X} 4=$ equity market price / liability face value & 0.004 \\
\hline $\mathrm{X} 5=$ sales revenue / total assets & -0.016 \\
\hline $\mathrm{X} 6=$ net cash flow / total assets & -0.041 \\
\hline $\mathrm{X} 7=$ accounts receivable / total assets & 0.000 \\
\hline $\mathrm{X} 8=$ inventory / total assets & 0.072 \\
\hline
\end{tabular}

In summary, the credit risk identification model established by Fisher discriminant is: $\mathrm{Z}=-0.704-0.038 \mathrm{X} 1+0.001 \mathrm{X} 2+0.033 \mathrm{X} 3+0.004 \mathrm{X} 4-0.016 \mathrm{X} 5-0.041 \mathrm{X} 6+0.072 \mathrm{X} 8$ $\mathrm{Z}$ is the discriminant value, if $\mathrm{Z}>0$ means that the company has financial difficulties, there is more likely to be unable to repay, if $Z<0$ means that the company's financial situation is good.

\subsubsection{Empirical Test}

According to the sample above, the $\mathrm{Z}$ discriminant model is tested as follows:

Table 5. empirical results of the new model

\begin{tabular}{|c|c|}
\hline Company name & $\mathrm{Z}$ \\
\hline *ST XiTan & 1.425038 \\
\hline *ST YingFang & -2.7255 \\
\hline ST ChengCheng & 0.924264 \\
\hline ST Hui Qiu & 0.663879 \\
\hline *ST Zhu Jiang & 0.6728878 \\
\hline *ST Heng Li & -0.2557843 \\
\hline *ST Xin Mei & 2.3153147 \\
\hline ST YaTai & -0.1982414 \\
\hline *ST HongSheng & 0.932307 \\
\hline *ST XingYe & 2.5402684 \\
\hline Tian Bao Ji Jian & -2.4871008 \\
\hline Yue Hong Yuan A & -1.2626683 \\
\hline Zhu Jiang Shi Ye & -3.1347414 \\
\hline Guang Yu Fa Zhan & -1.1081241 \\
\hline
\end{tabular}


Table 5, cont.

\begin{tabular}{|c|c|}
\hline Kong Gang Gu Fen & -1.7352713 \\
\hline Gao Xin Fa Zhan & -1.2117287 \\
\hline ShaHe GuFen & -1.7549424 \\
\hline Yuan Chen Huang Jin & $\mathbf{0 . 4 2 5 2 3 6}$ \\
\hline Rong Feng Kong Gu & -2.6667147 \\
\hline Jin Yu Che Cheng & $\mathbf{0 . 7 1 3 3 2 4 3}$ \\
\hline
\end{tabular}

According to discriminant, the deviation appears as a bold $\mathrm{Z}$ value. When using the new model, the probability of deviation is greatly reduced. Error probability of ST business is $30 \%$, and error probability of non-ST business is $20 \%$. Credit risk of ST and non-ST companies can be better identified.

This part uses the classical $\mathrm{Z}$ model to identify the credit risk of the listed company in the real estate industry, which proves that it cannot fully recognize the credit risk of the real estate industry. Therefore, the variable index is selected, and the Fisher discriminant method is used to design a new identification method of credit risk, and then the sample is verified.

\section{Conclusion}

Firstly, on the one hand, the shares of the listed company are divided into tradable shares and non tradable shares in China. The situation is unique in China's financial markets. On the other hand, China's financial market is not mature, the regulatory mechanism is not standardized and the stock market speculation is serious. Therefore, ST companies are generally considered to have higher credit risk, it will affect the accuracy of $Z$ model.

Secondly, the operating environment of each company is different, the nature of each company is different, the size of each company is different, so wo should take into account the variety of actual situation to use the $\mathrm{Z}$ model of credit risk identification.

Finally, the financial data of listed companies in China is not necessarily true, from this direction, the financial statements of listed companies should be strictly regulated.

In addition, the application of $\mathrm{Z}$ model is not limited to the real estate industry, but also for credit risk identification in other industries. 


\section{References}

Acharya, V., Davydenko, S.\& Strebulaev, I. (2012) "Cash Holdings and Credit Risk", The Review of Financial Studies, vol. 25, no. 12, pp. 3572-3609.

Deng, Y. (2016) "Credit risk and prevention of commercial banks under the new economic situation”, Journal of Hunan University of Science and Engineering, 01:97-100.

Guilherme, B. F. \& Rinaldo, A. (2016) "Spatial dependence in credit risk and its improvement in credit scoring", European Journal of Operational Research, 249(2).

Geonwoo, K. \& Eunho, K. (2016) "Closed-form pricing formula for Exchange option with credit risk", Chaos, Solitons and Fractals: the interdisciplinary journal of Nonlinear Science, and Nonequilibrium and Complex Phenomena.

Gourio, F. (2013) "Credit Risk and Disaster Risk" American Economic Journal: Macroeconomics, vol. 5, no. 3, pp. 1-34.

Guo, Y., Zhou, W., Luo, C. \& Liu, C. (2016) "Instance-based credit risk assessment for investment decisions in P2P lending”, European Journal of Operational Research, 249(2).

He, Z. \& Xiong, W. (2012) "Rollover Risk and Credit Risk", The Journal of Finance, vol. 67, no. 2, pp. 391-429.

Johanna, E., Nadine, G. \& Michael, M. (2016) "Valuation and risk assessment of participating life insurance in the presence of credit risk", Insurance Mathematics and Economics.

Ji, Z., Wang, X. \& Cao, N. (2014) "Internet credit, credit risk management and credit", Journal of Financial Research, (10): 133-147.

Jarrow, R. (2009) "Credit Risk Models” Annual Review of Financial Economics, vol. 1, 3768 .

Liu, M. \& Zhou, Y. (2012) "Credit risk analysis of commercial banks in China", Macroeconomic Research, (08): 92-96.

Luo, F. \& Chen, X. (2017) "Credit Risk Assessment and Application of Personal Microcredit Based on Logistic Regression Model", The Theory and Practice of Finance and Economics, (01): 30-35.

Longstaff, F., Pan, J., Pedersen, L.\& Singleton, K. (2011) "How Sovereign Is Sovereign Credit Risk?", American Economic Journal: Macroeconomics, vol. 3, no. 2, pp. 75-103.

Maria, R. S. (2016) “A new dynamic modeling framework for credit risk assessment”, Expert 
Systems with Applications, 45.

Wu, W., Kou, G.\& Peng, Y. (2016) “Group Decision-Making Using Improved Multi-Criteria Decision-Making Methods for Credit Risk Analysis", Filomat, vol. 30, no. 15, pp. 41354150 .

Yang, J. \& Liu, H. (2009) "Study on the method of measuring the economic capital of portfolio credit risk", Journal of Financial Research, (04): 143-158. 